\title{
Leadership Styles Of Women Entrepreneurs: An Exploratory Study At SME Sector At Karachi
}

\author{
Farooq-e-Azam Cheema \\ Bahria University Karachi Campus \\ Tayyaba Zarif \\ Shaheed Benazir Bhutto University
}

Aziz - un- Nisa

Department of Education

University of Karachi

\begin{abstract}
This study is an exploratory, based on leadership styles of women entrepreneurs in the SME Sector, of Karachi with an interpretive approach. The data has been collected through primary and secondary sources via in depth interviews and questionnaires on leadership styles The focus is on exploring their dominant leadership styles, influencing employees to achieve efficacy in their organizations. The study reveals that women entrepreneurs generated innovative business systems and culture which is based on their unique leadership styles that led to their success in the SME sector. The common denominators of success among these women were constant across the nature of business; size of the organization; industry; age; educational level; family support; and, previous work experience. The factors that basis to their success mainly are their shared personality traits of being hardworking, determined, dedicated, modest, challenge seekers, trend setters, motivated, innovative, multi-tasking and employee retention. The styles of leadership based on Robert Galford theory namely; ambassador, advocate, creative builder, truth seeker, experienced guide, people mover, revealed the veracity of their skills in leadership. The findings of study have a positive connotation and it will be beneficial for training and guiding of upcoming women entrepreneurs.
\end{abstract}

Keywords: Leadership Styles, Traits, Women Entrepreneurs, Empowerment.

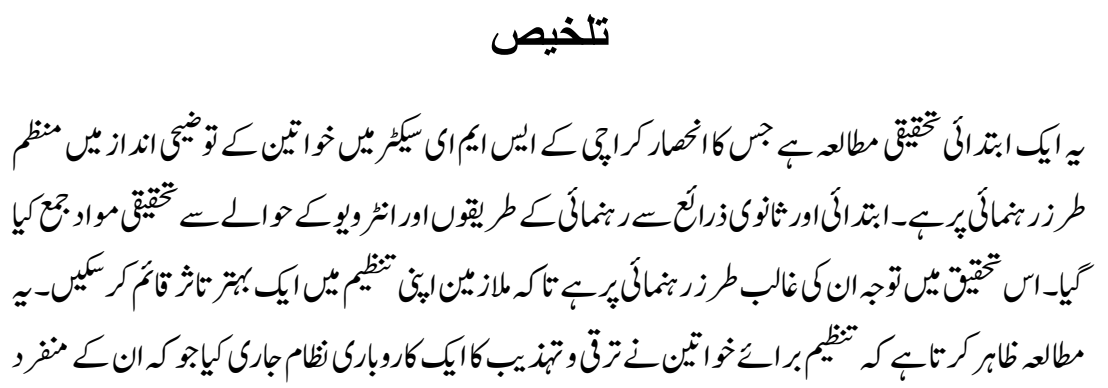




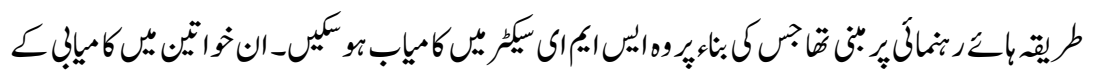

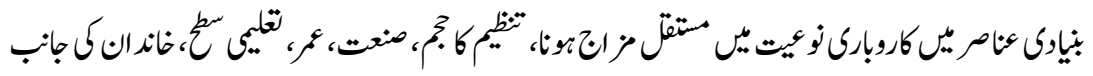

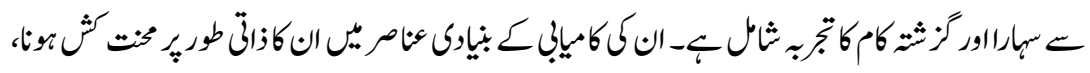

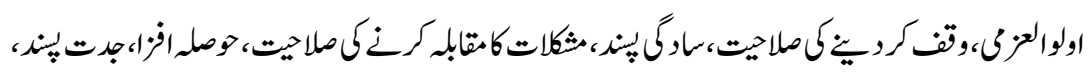

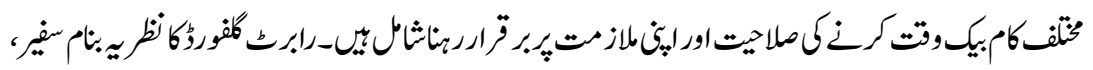

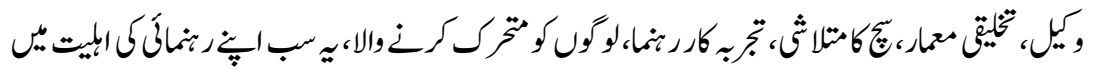

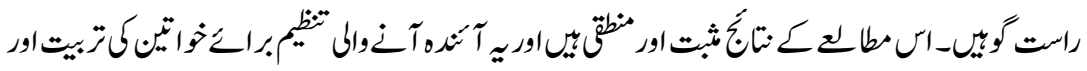

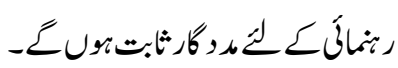

$$
\begin{aligned}
& \text { كليرىالفاظ:توضيحانداز، خوصيات،كروبإنواثين،باضتيار }
\end{aligned}
$$

\section{Introduction \& Aims of Research}

The major objective of this research is to explore and classify the different leadership styles and legacies of the successful women entrepreneurs of small medium enterprises (SME) in the Karachi metropolis. This study is of special importance keeping in view the patriarchal society of Pakistan where the women are assigned domestic label and are preferred to be seen in the role of a mother, sister and wife than an entrepreneur. As a result, majority of the women remain unaware about their business related potential and acumen. The issue is augmented by the feelings at large that the business can be started when one has large amount of money and an inherent knowledge of the business. In the result, most of our students male and female both take education mostly with an aim to adopt a service based career rather than undertaking entrepreneurship.

This issue is more relevant with the female young generation. Women get education frequently especially in the bigger cities of the country and do job as well but they are not frequently seen doing independent businesses. This situation is more aggravated because there is a common belief among the Pakistani society that business can be started only through big investment. But the idea of women entrepreneurship especially at the smaller scale has proved successful in Bangladesh under the aegis of the Grameen Bank.

But the worldwide statistics are quite different. For instance, Stanford et. al, (1992) say that women are starting new businesses at two to five times the rate of men in the U.S.; in fact, women-owned business is one of the fastest growing segments of the U.S. economy a current Small Business Administration (SBA) count tallied approximately 5 million women-owned businesses and the women-owned businesses were projected to surpass the 
fortune 500 in numbers of people employed.

In another study that featured a group of women who represented the majority of entrepreneurs and managers in a popular shopping center in a large metropolitan area, George, R. (1993) that there was a total absence of any specific gender-related references in these women's discussions. Rather, these female merchants credited their success to their ability to make a good planning, acquire the required resources, get the work done by others, and to fulfill the needs of their customers. Roomi (2005) says that successful women entrepreneurs have been found possessing traits like strong enterprising personality, determination, love for challenge and decision making, internal locus of control, and are creative and responsibility seekers. These traits are linked with unique leadership qualities and styles which these women possess. So the issue may be more a matter of degree of confidence than the resources required or the support available. As result of these findings, the researchers believed it would be possible to obtain a description of the personal leadership traits/styles possessed and then to developing an informed hypothesis, which will be fruitful for the further exhaustive research studies, upcoming women entrepreneurs and the established ones as well.

Consequently, this study is specially being undertaken to identify the business leadership style among some successful women entrepreneurs in the metropolis of Karachi who started their business mostly on their own and have been successfully running it at least for last ten years. These women were registered with the Women Chamber of Commerce and Industries (WCCI) Sindh. Findings of the study are likely to help the women in general to explore their own potential of entrepreneurship.

This study is based on the leadership style model offered by Robert M. Galford and Regina Fazio Maruca (2006) Harvard university professors and CEO of Centre for Leading Organizations in USA, in their book "Your Leadership Legacy." This model identifies various leadership styles possessed by the women like: Ambassador, Advocate, People Mover, Truth-Seeker, Creative Builder and Experienced Guide are taken for the study using a specially designed questionnaire.

\section{Literature Review}

Today's business world encompasses more challenges and obstacles, which evidently demands for entrepreneurial leader as a new kind of person who can come up with unconventional methods of running their ventures. In fact the entrepreneurial leadership has to use the combinations of diverse leadership styles in order to be successful in short run as well as long run (McLagan and Nel, 
1995). These conditions may be apparently well met by the male entrepreneur, women entrepreneurs have usually been assigned a negative connotation regarding their entrepreneurial abilities and leadership styles (Antonakis, 2005).

In a study of the management practices of men and women business owners subtitled "Gendered Rhetoric versus Business Behavior in Small Firms," Cliff, Langton, and Aldrich (2003) argue that women and men distinctively demonstrate that their execution is different whereas, in fact, their business style is more or less the same. Some researchers have raised questions that men and women differ in their leadership and management style. An interesting study of the high-tech industry (Perelman, 2001) found few gender differences, which is in contrary to the previous researches which are not based on the hightech industrial entrepreneurship.

Ingrid, et al (2002) Sexton and Bowman, (1986) and Sexton and Bowman-Upton $(1990$,) found that women differ from men lies in risk-taking as they are risk averters and men are risk takers, particularly, levels of diversification and type of leadership. Furthermore, they noted that male and female entrepreneurs experience different stresses as well (Shah, 2002; Asparay and Cohoon; 2007). There is a general belief that women face more obstacles in leadership than men do (Eagly et al., 2001) which is evident in Pakistani society. Female leaders have to put their extra effort in handling the conflicting demand and they are in constant mode of proving their abilities in order to be influential and successful (Eagly and Johannesen-Schmidt 2001).Women leaders experience negative reactions when they adopt the autocratic and directive style of leadership (Carli \& Eagly, 2003; Rudman \& Glick 2001). Consequently, Cantor and Bernay (1992) said there was a trend around two decades back among corporate women to dress up like men merely to show up their capabilities and potential of leadership.

Despite all these barriers in the way of women as entrepreneur, an overwhelming growth is found in the businesses who are owned and governed by women and have high success rate. To name few like Anita Roddick of Body Shop, Ping Fu a US based Chinese, founder of Raindrop Geonmagic a soft ware organization. Andrea Jung, CEO of Avon, Kiran Mazumdar of Biocon India. In United States of America, Oprah Winfrey the founder of Harpo group of Companies. In case of Pakistan Sam Abbas founder of designer furniture, Zeenat Ahmed of Taneez, Nabila as Beautician expert and Event management.

Stanford, H.J et al., (1993) say that in 1992, women-owned businesses were projected to surpass the Fortune 500 in numbers of people employed; women are starting new businesses at two to five times the rate of men; in fact, womenowned business is one of the fastest growing segments of the U.S. economy--a 
current Small Business Administration (SBA) count tallied approximately 5 million women-owned businesses and predicts women will own nearly 40 percent of small businesses by 2000; in the next decade, fully two-thirds of new entrants into the work force will be women; and, finally, the number of women in upper- level management has increased and is projected to increase well past the year 2012.

In developed countries the women entrepreneurs' concept was started in 20th century but in the Islamic history this is not new. Our Holy Prophet Hazrat Muhammad (Peace be upon him)'s, beloved wife Hazrat Khadija (May Allah be Pleased with her) was also a business woman. She was a trader, who used to send her products to Syria and Yemen. Business women are not disapproved in Islam (Haddad, et al., 1998) rather they are allowed to generate money making activities that can help to improve the economic state of the family, and the community.

Shah (2002) quotes Vijay Lakshami, an economist from Madras, India, "if entrepreneurship is defined as the ability to coordinate and organize, manage and maintain, and reap the best out of the worst situation, it is nothing new to women. The best and the most versatile example of woman entrepreneur can be found in the form of a daughter in law of joint family in the Indian society where she has to exhibit all entrepreneurial traits successfully. Similar finding is given by Helgesen (1990) who says that women wield the better entrepreneurial vision and traits than men since they simultaneously manage households, raise children, and juggle with careers.

Hackman, Furniss, Hills, \& Paterson, (1992), address another dimension of the leadership: transformational leadership and say that transformational leadership is apparently more associated with the female than the male because the female leaders opt for more participative and democratic and participative styles than their opposite counterparts (Eagly, etal., 2001; Riebe 2005; Ingrid, et al., 2002). The term transformational leadership was coined by Burns, in 1978. Bass and Avolio (1993) found that transformational leadership is made up of five factors: Idealized influence, inspirational motivation, intellectual stimulation, and individualized consideration. Eagly et al. (2001) and Yoder (2001) found that women exceeded men on three transformational scales: namely, idealized influence, inspirational motivation, and individualized consideration.

Stanford et al., (1995) say that women also exceeded men on even the transactional scale of contingent reward as well. This finding suggests that the female managers use reward as power to get their targets. Since women have to prove their credentials more diligently than men to be recognized as leaders, 
they have to use reward and referent powers to lead from front (Stanford, et al., 1995). A study by Buttner (2001) shows women exhibit good leadership style that encompasses good human relations, empathy, effective communication, teamwork, self-development and taking care of development of others. According to Riebe (2005) the sample of women entrepreneurs she studied were not all highly qualified yet they have improvised their own leadership styles in connection to their situations and based on their previous experiences and demonstrated a values-based approach to business and denounce the typical Boss and subordinate relationship.

Typology of Female Entrepreneur-Leaders in Malaysia introduced by Idris (2008) shows women may have a more flexible leadership style available to them. They are four distinct styles of female leadership namely, "Mother", "Teacher", "Boss" and "Chameleon", are described as; mother style exhibits a family-oriented approach in business management. Teacher highlights an educationist who supports and encourages in good academic qualification, training and continuous upgrading of skill and technology. The Boss, executes on the process of innovation. Different and new processes are adopted, the salary and progress are linked with the performance evaluation and meeting the organizations targets. Finally, the chameleon entrepreneur's reflects to be situational.

Another aspect of women entrepreneur leadership has been discussed in a study on Saudi Arabia Beverly (2009)the women's Arab League has facilitated human development efforts across Arab states. Increasing number of women attaining education and participating and entrepreneurial activities clearly exhibits there in born leadership skills and penchant to grow within the limits endorsed by Quran. Saudi Arabia is taking a quantum leap in developing the leadership skills of women entrepreneurs by creating a comprehensive centre in 2005, the Khadija bint Khuwalid Centre for Businesswomen. The council provides training in areas like public relations; computer skills; management of social services, management of voluntary associations; banking skills and capabilities. Interesting fact is that in five years time the Bahrain Chamber of Commerce from zero female members to 1785 (Beverly, 2009).

FWB report (2008) shows that the success rate of women is high in SME sector because for them defaulting a loan is like earning a bad name to the family. The moral fiber is different in women rom men, only a fraction of women have defaulted due to political forum's strong support (Raza, 2010). Besides, even when compared the women technology entrepreneurs with the women technical managers, the former were found more reflective, analytical, evaluative, logical, future-oriented, and with greater emotional energy in comparison to the women technology managers. 


\section{Research Method}

The research work is of exploratory nature wherein the leadership styles of the women entrepreneur in small and medium business in the city of Karachi were identified for creating a role model for the other women. Data was of primary nature collected through a questionnaire and the in-depth interviews. Findings accrued from the interviews were used to identify the factors underpinning the level of score for a particular style. Questionnaire and interview data findings are interwoven to undertake discussion and reach the conclusion.

\section{Sample Size and Composition}

A list of 112 entrepreneur women was provided by the by the Women Chamber of Commerce and Industries (WCCI) Sindh. On convenience basis a sample of 40 women entrepreneurs were selected for questionnaire data. Since the exact number of members of women entrepreneurs was not documented with the WCCI, one cannot claim that the list of women entrepreneur was a valid population in the in the city of Karachi. Sampling was based on the following criteria:

i. At least co-initiator of the business

ii. 10 years or longer association with the business

iii. Working as CEO/Directors of their organization

Among our samples, 31\% had 21-28 years of duration, $34 \%$ had business of 13-20 years of duration, and 23\% had 5-12 years of business duration. Regarding educational qualification, $12 \%$ of the respondents had Master's degree, $8 \%$ had a $\mathrm{PhD}, 52 \%$ had bachelor's degree, 12\% Intermediate, 3\% matriculate, $12 \%$ had an MBA, 10\% had a BBA and 3\% Bachelors in interior designing. Regarding marital status, $80 \%$ of our respondents were married, $12 \%$ are divorced, $4 \%$ widowed and $4 \%$ are unmarried. Their fathers or husbands had supported them in initial set up of the businesses. One respondent is doing her business with her brother and the other one with her son. The age group ranged from 35 to 60 .

\section{Questionnaire Data}

The questionnaire was borrowed from Robert M. Galford and Regina Fazio Maruca (2006) Harvard university professors and CEO of Centre for Leading Organizations in USA whose model was used for this research work. This questionnaire was required to be filled online to be worked out and the findings tabulated by the authors of the questionnaire Galford and Maruca (2006) themselves rather than by the researchers. The questionnaire carried 30 questions and the findings would result into typology of six leadership dimensions/styles. 


\section{i. Ambassador}

Leaders executing the ambassador style are generally well versed in handling difficult situation. They are persistent and can introduce people-assessments and development frameworks. As a result employees understand them and follow them respectfully.

\section{ii. Advocate}

Leaders having advocacy style exhibit acts as being spokesperson in a group. They are practical, articulating, coherent, and influential. They are relentless positively coming up with new ideas. Therefore, they need ambassadors as their senior management teams to persuade employees to "buy into" their decisions.

\section{iii. People Mover}

People Movers are team builders and natural mentors. Interestingly they have large contact lists. They are always coming up with new ideas for moving others and are also poised to get the same from otherss. They are always vigilant about their subordinates' work.

\section{iv. Truth-Seeker}

Truth-seekers facilitate people to understand new rules and policies while maintaining the veracity of processes. They try to identify the root-cause of the issues, keep objectivity standard high, and believe in transparency. They provide equal opportunity for all.

\section{v. Creative builder}

Creative builders are visionaries; they are happiest and most driven at the start of things. They look for new opportunities for new products, new companies; spot niche markets; take ideas and make them real.

\section{vi. Experienced Guide}

These individuals are good listeners, natural therapists. They have endless information on a diverse range of topics. They may not be necessarily experienced and mediators, yet they are often the person to whom people like to consult. They mostly go for win- win solutions.

Each leadership style mentioned above carried 30 points in maximum. There were three levels of intensity along the points scale: score of 23 and above points indicated exhibition of high intensity in that style, score of 21-22 points range indicated moderately high intensity, and the score of $18-20$ points range indicated low intensity exhibition for that style.

Results scored by the 26 respondents in the questionnaire were tabulated in the Matrix 1 below: 
Matrix: 1

Questionnaire Data

\begin{tabular}{|l|c|c|c|c|}
\hline Leadership Style & $\begin{array}{c}\text { High } \\
\text { Intensity } \\
\text { Scorers }\end{array}$ & $\begin{array}{c}\text { Moderately } \\
\text { High } \\
\text { Intensity Scorers }\end{array}$ & $\begin{array}{c}\text { Low } \\
\text { Intensity } \\
\text { Scorers }\end{array}$ & Others \\
\hline Ambassador & $19 \%$ & $27 \%$ & $46 \%$ & $8 \%$ \\
\hline Advocate & $23 \%$ & $19 \%$ & $39 \%$ & $19 \%$ \\
\hline Truth Seeker & $62 \%$ & $19 \%$ & $15 \%$ & $4 \%$ \\
\hline People Mover & $27 \%$ & $38 \%$ & $23 \%$ & $12 \%$ \\
\hline Creative Builder & $19 \%$ & $50 \%$ & $19 \%$ & $12 \%$ \\
\hline Experience Guide & $20 \%$ & $35 \%$ & $30 \%$ & $15 \%$ \\
\hline
\end{tabular}

\section{Overall Leadership Style Preference among the Respondents}

High and moderately high intensity scores were added to ascertain an overall leadership style preference among the respondents. This leadership style preference is shown below arranged in ascending order of the intensity scored by the respondents for that style.

Matrix: 2

Overall Leadership Style

\begin{tabular}{|l|c|}
\hline Leadership Style & \%age of the Respondents \\
\hline Truth Seeker & $81 \%$ \\
\hline Creative Builder & $69 \%$ \\
\hline People Mover & $65 \%$ \\
\hline Experience Guide & $55 \%$ \\
\hline Ambassador & $46 \%$ \\
\hline Advocate & $42 \%$ \\
\hline
\end{tabular}

\section{Discussion}

\section{In the Ambassador Style}

$19 \%$ of entrepreneurs showed highest intensity in this style whereas $27 \%$ showed moderately high intensity for this style. It means only less than half of the respondents scored high and moderate high in this style. Raza's (2010) point of view in this regard is relevant. She (ibid) says that in our society women are more treated as mother, sister, daughter and wife - all dependent roles - than an independent member of the society and, in the result, they do not get the problem solving skills developed. Interview data shows that majority of the respondents had support of any of the male member of the family available in beginning of the business. Ingrid, et al (2002) found women as risk averters as compared to the men entrepreneur who they found as risk takers. Being risk averter is an affront to the ambassadorship style of this model. 
Eagly et al., 2001 also believe that women face more obstacles in dealing with the business related problems than men do which diminishes their confidence in problem-solving. Carli \& Eagly, (2003) support this point saying that women leaders experience more negative reactions when they become aggressive to the societal and bureaucratic roles as compared to their male counterparts. Perhaps only why, as described by Cantor and Bernay (1992), the corporate women had to dress up like men two decades back just to show up their capabilities and potential of leadership.

However, those respondents who scored high intensity level believed in self concept. These respondents were found resilient, determined, and selfconfident in their outlook holding true to their score. They narrated the difficulties in running their business especially in the outset. The way they overcame those difficult situations in fact proved their high inclination towards ambassadorship in terms of definition given by this model.

\section{In Advocate Style}

This was the least scored leadership style by the respondents. On this leadership style, $23 \%$ of the respondents scored the highest intensity, $19 \%$ scored moderate and $39 \%$ of the respondents marked the low intensity score. One may again resort to the reason assigned by Raza (2010) that our women have been brought up in the dependent role that dampens their confidence required by the "Ambassador" and "Advocate" styles. One may get a clue from the work of McLagan and Nel, (1995) to elucidate this situation who say that today's business world encompasses more challenges and obstacles, which evidently demands for entrepreneurial leader as a new kind of person who can come up with unconventional methods of running their ventures, that the female business adventurers show up comparatively low than the businessmen.

However, the respondents who scored high on this style were found to be articulate, rational, logical, and persuasive. They tended to be relentless, positive, and coming up with new and pragmatic ideas to lead their organizations in order to be the leader in their particular category. One of these high scoring respondents said, "I always look for new ideas, opportunities to improve my work, because my work is easily copied. Therefore I change my menu off and on in this way I remain competitive."

\section{In People Mover Style}

People-mover style got the third highest (65\%) score among the respondents. This is perhaps the women's natural instinct to treat their workers as a family which men cannot stated by one respondent (Raza, 2010). Most of these 
respondents were found with career builder and parental nurturing outlook. One respondent was found encouraging her employees to pursue further education. As a result of such nurturing initiatives, her former driver returned to be her accountant. Most of these respondents were found giving employees a great deal of appreciation and recognition, so much so that four of the respondents had their employees involved in profit sharing deal in the business. $70 \%$ of the respondents had employees working for them for more than 20years. They were concerned about and looked after their lives. Majority of the respondents were of the view that salary alone was not enough rather the employers should address the humane and emotional side of the people. One of the respondents had been rearing children of one of her employees who died of cancer during her employment. Other respondent stated "People who make sofa never sits on it, therefore it is our duty to make them empower so they can have a decent life". Still another respondent said, "My whole business after me will be automatically transferred to my senior designers as they are the one running show they deserve more to have it." One of them said, "I learn from my juniors, as they give me fresh ideas for work, and even when my sweepers do not come I clean the bathrooms to set an example"

\section{In Truth-Seeker Style}

Truth-seeker style proved the highest scored (81\%) style during the study. One of the respondents said, "A woman should be honest in her dealing, firstly her name is attached with the family and secondly by keeping her good name she is creating credibility." Raza (2010) also found in her work that success rate of women in the SME is high because for them defaulting a loan is like earning a bad name to the family. As the moral fiber is different in women, only a fraction of women have defaulted due to political forum as a support says FWB (2008) report. Another respondent said, "She can tolerate mistakes but not a lie and any mode of cheating." She says 'it's not worth wasting time on such individuals." Another respondent stated "I believe in being honest with my product because only consistent fairness in the product makes us grow in business".

Majority of the respondents opined against using short cuts to success and showed their express belief in quality that should never be compromised. To them, being ethical, honest and transparent at every level was essential. High score in truth-seeker style seems to have its roots in spiritual mindset of majority $(92 \%)$ of the respondents as they claimed that they believe in their efforts but they associate it with the help of God, Almighty. One of the respondent said "I always pray to Allah for a legitimate income." All respondents had their companies registered with the income tax and sales tax and had very transparent accounts maintained. One of the respondents said, 
"My all audit reports are properly documented and published on line, anyone can see them."

\section{In Creative-Builder Style}

Creative-builder leadership style fetched second highest (69\%) score among the respondents. Majority of entrepreneurs opted for those businesses in which they had expertise and they wanted to create a different perception about their products. They wanted to be trendsetter and monitored the entire work throughout its implementation. $99 \%$ of the respondents emphasized that a woman should be multi tasking and organized in order to be an achiever. All of the respondents had provided their workers all necessary resources including modern tools for work. An employee of one of the respondents said, "My boss has revived the dead silver industry that is a favour to the not-so-rich segment of the society." The respondent herself said, "Silver ware was an obsolete concept among the consumers, I tried to revamp the old silver ware concept in to new products like making doors of silver or edging on the furniture, the idea was well accepted by the consumer." One of the respondents started her business by using fabric waste of his husband's business and converted it into upholstery material. One respondent claimed that when she saw her designs copied ever she changed the whole line of her brand. Another respondent had converted the plastic and paper garbage into bricks and other material for construction.

\section{In Experienced Guide Style}

Experienced Guide leadership style fetched a moderate score $(55 \%)$ among the respondents. Those who scored good on this style were found having exceptionally good listening habits, "I take inspiration from the youngsters and merge the new with the old technology, and this is how my daughters-in-law are working as head of their departments." One of the respondents said, "My daughters-in-law work along with me in my TV channel. It may not be apparently an easy job. But I listen to their ideas and give them complete freedom to execute their ideas. However, mostly they turn up to me for advice in the end." Majority of the respondents underscored they empathize for their employees and sort out the issues with their suggestions. One respondent said, "When my old employees come for advice to launch their business, I go out of the way to help them start their projects. My three former employee teachers are now running their own Montessori." Other respondent was elated to say, "People come to me for advice for they believe I am not judgmental". Still other respondent said, "When I will not be in this world this organization shall keep its pace because I have built the system and have groomed the people through delegating work to them." Majority of the respondents claimed they do the jobs of the lower staff in 
their absence. Even if the janitor was absent they did not hesitate to wash bathrooms.

\section{Conclusions}

The study unfolds the various leadership styles of women entrepreneurs of Karachi along the Robert Galford and Regina Fazio Maruca (2006) scale, and then through the interview data effort was made to identify the underpinning factors for the level of score gained for a particular style. This study especially shows how these women trudged through the difficulties inherent in the patriarchal society like Pakistan. Majority of them had not acquired any proper degree of business management but a good mix of leadership styles have made them successful entrepreneurs. The study is likely to develop an informed hypothesis about connectivity of leadership style and the business success among the female entrepreneur, which will be fruitful for the upcoming women entrepreneurs as well as the established ones especially keeping in view the rise in the successful growth of women entrepreneurs in Pakistan in general and Karachi in particular. However, further exploratory study is proposed to work on the leadership legacies of the women entrepreneurs of Karachi, who have emerged not only as successful individuals but are also as trend setters for other women.

\section{References}

Antonakis, J., Angerfelt,M. \& Sivasubramaniam, N. (2005). When They Were Good They Were Very Good Indeed But When They Were Bad They Were Horrid! Biasing Effects On Ratings Of Leadership, Paper Presented At Women As Global Leaders Conference, March 14-16, 2005 Dubai

Aspray, W. \& Cohoon. J. McGrath (2007). Women's Entrepreneurship in the Information Technology Field Positive Illusions, Motivations, Management Style, Stereotypes, Stress, and Psychological Traits, National Center for Women \& Information Technology

Bass, B.M. \& Avolio, B.J. (1993). Transformational Leadership: A Response to Critiques, In M.M. Chemers \& R. Ayman (Eds.), Leadership theory and research (pp. 49-80). San Diego: Academic Press

Beverly, D. M. (2009). Developing Women's Leadership Capability in the Public Sector in the Middle East, International Conference on Administrative Development: Towards Excellence in Public Sector Performance, King Faisal Hall, Riyadh, KSA, 
Burns, J.M. (1978). Leadership. New York: Harper \& Row

Buttner, E.H. (2001). Examining Female Entrepreneurs' Management Style: An Application of a Relational Frame, Journal of Business Ethics vol. 29, pp. 253-269 Stable URL: http://www.jstor.org/stable/25074459 Accessed: 09/03/2010 01:45z

Carli, L. L. \& Eagly, A. H. (2003). The Female Leadership Advantage: An Evaluation of the Evidence, The Leadership Quarterly, 14, 807-834

Cantor, D. W. \& Bernay, T. (1992). Women in Power-the Secrets of Leadership. Boston, MA: Houghton Company.

Cliff, J., Langton, N. \& Aldrich, H. (2003). On their Own Terms? Gendered Rhetoric Versus Business Behaviour in Small Firms, Center for Women's Business Research: National Foundation of Women Business Owners, retrieved 3-3-2010 from http://www.womensbusinessresearch.org/bestpaper2003

Eagly, A.H. \& Johannesen-Schmidt, M.C. (2001). The Leadership Styles of Women and Men, Journal of Social Issues, vol.57, pp.781-797.

Eagly, A.H. \& Johnson, B.T. (1990). Gender and Leadership Style: A MetaAnalysis. Psychological Bulletin, vol.108, pp.233-256.

Galford. R \& Maruca. F. R (2006). Your Leadership Legacy, Harvard Press.

George, R. (1993). Women in Majority. Corpus Christi Caller-Times, pp. B5B6.

Haddad, Y. \& Esposito, J. Eds. (1998). Islam, Gender and Social Change, NYC: Oxford University Press.

Hackman, M. Z., Furniss, A. H., Hills, M. J. \& Paterson, T. J. (1992). Perceptions of Gender-Role Characteristics and Transformational and Transactional Leadership Behaviours. Perceptual and Motor Skills, vol.75, pp.311-319

Helgesen, S. (1990). The Female Advantage-Women's Ways of Leadership. New York: Doubleday

Idris, A. (2008). Cultivating Innovation through Female Leadership:, University of Malaya, Journal of Asian Social Science, vol.4:6. 
Ingrid, V., Risseeuw, P. \& Bartelse, G. (May 2002). Gender Differences In Strategy and Human Resource Management: The Case of the Dutch Real Estate Brokerage, International Small Business Journal 8.

Langan-Fox, J. \& Roth, S. (1995). Achievement Motivation and Female Entrepreneurs, Journal of Occupational and Organizational Psychology vol.68, pp.209-218.

Perelman, A. (2001). Women Entrepreneurs: A Comparative Analysis of Decision Style in High-Tech, Dissertation Abstracts International 61 (8-B), p. 4459 (UMI No. AAI9984823).

Raza, Tahira (2010). Executive Vice President, Chief Risk Officer, National Bank of Pakistan. Head Risk Management Division \& Wing Head CMS\&C CMG National Bank of Pakistan, Karachi, and former First Women Bank employee, personal communication on 2-7-10.

Riebe, M. (2005). The Leadership Style of Women Entrepreneurs: An Alternative Model of Successful Management Practices Center for Women Entrepreneurs and Entrepreneurship, retrieved from: www.sbaer.uca.edu/research/icsb/2005/163.pdf.

Rosener, J.B. (1990). Ways Women Lead, Harvard Business Review, November December 1990, pp. 119-125

Roomi. M.A. (2005). Women Entrepreneurs in Pakistan: Profile, Problems, and Policy Recommendations, Paper Presented at 51 st ICSB Conference, Washington, D. C., USA.

Rudman, L. A. \& Glick, P. (2001). Prescriptive Gender Stereotypes and Backlash Toward Agentic Women, Journal of Social Issues 12.

Sexton, D.L. \& Bowman, N. (1986). Validation of a Personality Index: Comparative Psychological Characteristics Analysis of Female Entrepreneurs, Managers, Entrepreneurship Students, and Business Students, Frontiers of Entrepreneurship Research pp. 18-25. Wellesley, MA: Babson College.

Sexton, D.L. \& Bowman-Upton. N. (1990). Female and Male Entrepreneurs: Psychological Characteristics and Their Role in Gender Related Discrimination, Journal of Business Venturing, vol.5:1, pp.29-36 
Shah, N. A. (2002). Changing Role of Women In Pakistan: A Study of Social and Economic Activities Of Women Entrepreneurs, Dissertation Submitted in Fulfillment of the Requirements For the Degree of Doctor of Philosophy in Social Work in Karachi University

Stanford, J.H., Oates, B.R. \& Flores, D. (1995). Women's Leadership Styles: A Heuristic Analysis, Women in Management Review, vol.10:2, pp.9-16.

Vroom, V. H. \& Yetton, P. W. (1973). Leadership and Decision-Making. University of Pittsburgh Press.

Yoder, J. D. (2001). Making Leadership Work More Effectively for Women, Journal of Social Issues 12.

Dr. Farooq-e-Azam Cheema is Professor in the Department of Management Science, Bahria University Karachi Campus, Karachi.

Dr. Tayyaba Zarif is Professor in the Department of Education, Shaheed Benazir Bhutto University Shaheed Benazirabad.

Aziz - un- Nisa is Lecturer in the Department of Education, University of Karachi. 